OPEN ACCESS

Edited by:

Qiang Wang,

Henan University, China

Reviewed by:

Konrad Szocik,

University of Information Technology and Management in Rzeszow, Poland

Wei Cong,

Key Laboratory of Green Process and Engineering, Institute of Process

Engineering, Chinese Academy

of Sciences, China

Jens Hauslage,

German Aerospace Center, Helmholtz

Association of German Research

Centers (HZ), Germany

${ }^{*}$ Correspondence:

Natalie Leys

natalie.leys@sckcen.be

Specialty section:

This article was submitted to

Microbiotechnology,

a section of the journal

Frontiers in Microbiology

Received: 23 April 2021

Accepted: 07 June 2021

Published: 29 June 2021

Citation:

Fahrion J, Mastroleo F

Dussap C-G and Leys N (2021) Use

of Photobioreactors in Regenerative

Life Support Systems for Human

Space Exploration.

Front. Microbiol. 12:699525.

doi: 10.3389/fmicb.2021.699525

\section{Use of Photobioreactors in Regenerative Life Support Systems for Human Space Exploration}

\author{
Jana Fahrion 1,2, Felice Mastroleo', Claude-Gilles Dussap ${ }^{2}$ and Natalie Leys ${ }^{1 *}$ \\ ${ }^{1}$ Interdisciplinary Biosciences Group, Belgian Nuclear Research Centre (SCK CEN), Mol, Belgium, ${ }^{2}$ CNRS, SIGMA \\ Clermont, Institut Pascal, Université Clermont Auvergne, Clermont-Ferrand, France
}

There are still many challenges to overcome for human space exploration beyond low Earth orbit (LEO) (e.g., to the Moon) and for long-term missions (e.g., to Mars). One of the biggest problems is the reliable air, water and food supply for the crew. Bioregenerative life support systems (BLSS) aim to overcome these challenges using bioreactors for waste treatment, air and water revitalization as well as food production. In this review we focus on the microbial photosynthetic bioprocess and photobioreactors in space, which allow removal of toxic carbon dioxide $\left(\mathrm{CO}_{2}\right)$ and production of oxygen $\left(\mathrm{O}_{2}\right)$ and edible biomass. This paper gives an overview of the conducted space experiments in LEO with photobioreactors and the precursor work (on ground and in space) for BLSS projects over the last 30 years. We discuss the different hardware approaches as well as the organisms tested for these bioreactors. Even though a lot of experiments showed successful biological air revitalization on ground, the transfer to the space environment is far from trivial. For example, gas-liquid transfer phenomena are different under microgravity conditions which inevitably can affect the cultivation process and the oxygen production. In this review, we also highlight the missing expertise in this research field to pave the way for future space photobioreactor development and we point to future experiments needed to master the challenge of a fully functional BLSS.

Keywords: space exploration, bioregenerative life support systems, microalgae, photobioreactors, air revitalization, cyanobacteria

\section{INTRODUCTION}

Human space exploration aims to go farther into space and crewed missions are planned to Moon and Mars. The European Space Agency (ESA) as well as the National Aeronautics and Space Administration (NASA) plan human missions to Mars in the coming decades (Hufenbach et al., 2014; Anderson et al., 2019). The space travelers need oxygen, fresh water and nutritional food to survive on such space missions (MacElroy and Bredt, 1984) and the supply has to become independent from Earth. In order to minimize the resupply needs and the embarked mass, the recycling process will have to include food production coupled to oxygen $\left(\mathrm{O}_{2}\right)$ and water $\left(\mathrm{H}_{2} \mathrm{O}\right)$ recovery that entails the use of at least one biological compartment for producing edible biomass. This challenge can be solved by the development of a bioregenerative life support system (BLSS), 
that meets the needs at least for a part of food supply to the crew and secures air, water as well as safe waste recycling (Gitelson et al., 1976).

This review will focus on the bioprocess of microbial photosynthesis and, in particular, on photobioreactors (PBRs) used in space for BLSS. Moreover, we focus on the process of air revitalization, meaning the efficient removal of carbon dioxide $\left(\mathrm{CO}_{2}\right)$ and production of $\mathrm{O}_{2}$. The goal of this study is to give an overview of the experiments that have been conducted with liquid cultures of photosynthetic microbes and PBRs for application in space, and to highlight similarities and common challenges. Hereby, the last 30 years will be focused. Additionally, missing data and suggestions on future experiments will be discussed. The following sections describe the general requirements for life support systems and the current state of the art to how a BLSS can be developed using different techniques and organisms.

\section{OXYGEN REQUIREMENTS AND CARBON DIOXIDE LIMITS IN SPACE HABITATS}

In our daily lives, $\mathrm{O}_{2}$ is freely available to us because our atmosphere functions as an infinite buffer tank for $\mathrm{O}_{2}$ produced by Earth's photosynthetic biosphere. However, when humanity wants to explore space, closed spacecraft do not have an endless supply of $\mathrm{O}_{2}$. Due to the human respiration process, the $\mathrm{O}_{2}$ level decreases while $\mathrm{CO}_{2}$ and water vapor $\left(\mathrm{H}_{2} \mathrm{O}_{\text {vapor }}\right)$ increase inside a closed habitat over time. The typical respiratory rate for a healthy adult at rest is $12-18$ breaths per minute or roughly 20,000 breaths a day (Crockett et al., 2018). In spacecraft environments, it is considered that one standard $82 \mathrm{~kg}$ crew member consumes $0.82 \mathrm{~kg} \mathrm{~d}^{-1} \mathrm{O}_{2}$ and produces $1.04 \mathrm{~kg} \mathrm{~d}^{-1} \mathrm{CO}_{2}$ and $1.85 \mathrm{~kg} \mathrm{~d}^{-1} \mathrm{H}_{2} \mathrm{O}_{\text {vapor }}$ during intravehicular activities. Based on these values, the respiratory quotient (mole $\mathrm{CO}_{2}$ produced per mole $\mathrm{O}_{2}$ consumed) is 0.92 , but the respiratory quotient varies depending on the physical workload, diet and individual metabolism (Anderson et al., 2018). When the partial pressure of $\mathrm{CO}_{2}$ in the air becomes too high, it becomes toxic to humans. For example, a maximum value for $\mathrm{CO}_{2}$ of $\leq 0.52 \mathrm{kPa}(0.52 \%$ per volume or $5,200 \mathrm{ppm}$ ) is allowed on the International Space Station (ISS) (Anderson et al., 2018) and even $0.50 \%$ $(5,000 \mathrm{ppm}) \mathrm{CO}_{2}$ in a habitat is thought to have a negative impact to human health over longer periods. In order to keep the risk of headache development under $1 \%$, the average value over 7 days should not exceed $\sim 0.33 \% \mathrm{CO}_{2}$ (Law et al., 2014). Consequently, a system is needed to remove excess $\mathrm{CO}_{2}$ and provide a sufficient partial $\mathrm{O}_{2}$ pressure. The partial $\mathrm{O}_{2}$ pressure depends on the total cabin pressure and should range between 18 and $23.1 \mathrm{kPa}$ or $21-50 \%$ per volume, respectively (Lange et al., 2003; Swickrath and Anderson, 2012; Anderson et al., 2018). On the ISS, the total pressure is set at $101.3 \mathrm{kPa}$ (with $\left.21 \% \mathrm{O}_{2}\right)$, so it resembles the pressure on Earth $(101.325 \mathrm{kPa}$ on sea level). But other pressure regimes are also suitable for manned habitats. When using atmospheres consisting of mixed gasses (e.g., $\mathrm{N}_{2} / \mathrm{O}_{2}$ mixtures), total pressures between 48.0 and $102.7 \mathrm{kPa}$ are acceptable. In early space missions, almost pure $\mathrm{O}_{2}$ atmospheres at total pressure of $34.5 \mathrm{kPa}$ were used. Due to the increased fire hazard under pure oxygen atmospheres, nowadays spacecraft use gas mixtures similar to our atmosphere (Lange et al., 2003; Anderson et al., 2018).

\section{PHYSICOCHEMICAL AIR REVITALIZATION IN SPACE HABITATS}

To date all crewed spacecraft solely rely on physicochemical methods of air revitalization. In the first years of crewed spaceflight, different physicochemical methods were tested. Early space missions like Mercury, Gemini, the Apollo Command Module and the Apollo Lunar Module used lithium hydroxide $(\mathrm{LiOH})$ canisters that remove $\mathrm{CO}_{2}$ by converting atmospheric $\mathrm{CO}_{2}$ to lithium carbonate $\left(\mathrm{Li}_{2} \mathrm{CO}_{3}\right)$ (Winton et al., 2016). The canisters have to be replaced after usage because the chemical reaction is irreversible. Additionally, different molecular sieves were used to remove $\mathrm{CO}_{2}$ and $\mathrm{H}_{2} \mathrm{O}_{\text {vapor. }} \mathrm{O}_{2}$ storage was usually accomplished via high pressure liquid $\mathrm{O}_{2}$ or chemically bound $\mathrm{O}_{2}$.

On the ISS, a Carbon Dioxide Removal Assembly (CDRA), an Oxygen Generation Assembly (OGA) and a Carbon Dioxide Reduction Assembly (CRA), are currently used to maintain a suitable gas balance. These systems use regenerable absorbent materials (in CDRA), water electrolysis (Eq. 1) (in OGA) and the Sabatier reaction (Eq. 2) (in CRA) to remove $\mathrm{CO}_{2}$ and produce potable water $\left(\mathrm{H}_{2} \mathrm{O}_{\text {potable }}\right)$ (Mansell et al., 2011; Knox and Stanley, 2015; Takada et al., 2019).

$$
\begin{aligned}
& 2 \mathrm{H}_{2} \mathrm{O} \rightarrow 2 \mathrm{H}_{2}+\mathrm{O}_{2} \\
& \mathrm{CO}_{2}+4 \mathrm{H}_{2} \rightarrow \mathrm{CH}_{4}+2 \mathrm{H}_{2} \mathrm{O}
\end{aligned}
$$

The methane produced in the CRA is vented into space. Considering a respiratory coefficient near than unity, the mol quantities of $\mathrm{O}_{2}$ to produce and $\mathrm{CO}_{2}$ to remove are almost equal. This means that the stoichiometric eqs. $(1,2)$ show that there is a global hydrogen imbalance. Either it must be compensated by hydrogen resupply or excess $\mathrm{CO}_{2}$ has to be removed by absorption to materials that end up as trash. As a consequence, substantial amounts of carbon and other elements are lost over time (Mansell et al., 2011; Knox and Stanley, 2015). So even nowadays, all of the methods used for air revitalization are physicochemical and not regenerative (Junaedi et al., 2011; Tobias et al., 2011). They use a lot of consumables and produce a lot of waste and are therefore only applicable for near-by (LEO) missions with easy resupply from Earth (Daues, 2006).

\section{BIOREGENERATIVE AIR REVITALIZATION IN SPACE HABITATS}

Possible solutions to this problem are photosynthetic biological systems using plants, algae and cyanobacteria for air revitalization and carbon recycling coupled to production of edible biomass. The photosynthetic activity of these organisms 
captures $\mathrm{CO}_{2}$ and $\mathrm{H}_{2} \mathrm{O}$ to produce edible biomass and $\mathrm{O}_{2}$. The development of a BLSS to ensure the autonomous air supply of space crews on distant and long-duration missions, became a long time goal of many space agencies (Lasseur et al., 2010). The first ideas on this topic were already developed around 1900 (Salisbury et al., 1997) and the development process has already started in the 1960s before the first human flew to space. Many different attempts to obtain such a BLSS with efficient biological air revitalization were conducted during the second half of the 20th century. Especially the soviet space program investigated different approaches using microalgae and higher plants very early (Hooke et al., 1986; Niederwieser et al., 2018).

Additionally, several test sites were developed on Earth. Some examples of large ground based studies are the BIOS-I project, where the algae Chlorella provided $\mathrm{O}_{2}$ for one human and the BIOS-III project that inhabited three crew members; plants and green algae performed at the BIOS facility in Krasnoyarsk, Siberia, Russia (Kirensky et al., 1968; Gitelson et al., 1976; Gitelson, 1992). The NASA Biomass Production Chamber project was a closed greenhouse designed to grow crops on a small area $\left(20 \mathrm{~m}^{2}\right)$, that was successfully operated for over 1,200 days (Wheeler et al., 1996). Another example is the Biosphere-2 project (in Oracle, AZ, United States), which tried to mimic the terrestrial biosphere by inhabiting eight crew members together with various plants (Allen and Nelson, 1997). A recent example is Lunar Palace 1, that investigated a system consisting of plants, insects and three crew members for 105 days ( $\mathrm{Fu}$ et al., 2016). ESA has initiated the development of its own Micro-Ecological Life Support System in 1988, called MELiSSA, combining physicochemical technologies with microbial and plant conversion of organic and inorganic waste into nutrients, and biological air revitalization (Lasseur et al., 2010). In addition to carbon, hydrogen and $\mathrm{O}_{2}$ balances, the MELiSSA loop considers the recycling of nitrogen, which in turns incorporates food production by biological compartments coupled to the other balances. The MELiSSA loop consists of five interconnected compartments including two PBRs. Compartment III holds a nitrifying culture to produce nitrate for compartments IVa (cyanobacteria) and IVb (higher plants), which use the nitrate, excess $\mathrm{CO}_{2}$ from the crew and light to produce edible biomass, potable water and $\mathrm{O}_{2}$ (Gòdia et al., 2002). The photosynthetic cyanobacterium Limnospira indica, formerly known as Arthrospira sp. PCC8005 (Nowicka-Krawczyk et al., 2019) is used as part of the $\mathrm{O}_{2}$ and edible biomass production in one of the PBRs (Poughon et al., 2020).

\section{PHOTOSYNTHETIC MICROORGANISMS AS CATALYSERS FOR AIR REVITALIZATION IN SPACE}

As mentioned above, air revitalization can be achieved by photoautotrophic organisms like cyanobacteria, algae or plants. In general, algae and cyanobacteria have many benefits compared to land plants for $\mathrm{CO}_{2}$ removal, and $\mathrm{O}_{2}$ and biomass production. Due to these benefits, unicellular photosynthetic organisms are investigated as key component of life support systems for a long time (Averner et al., 1984; Niederwieser et al., 2018).

\section{Oxygen Production and Carbon Fixation}

The light intensity is a key factor for $\mathrm{O}_{2}$ production in photosynthetic organisms. On the surface of Earth, the light intensity has a maximum of 2,500 $\mu \mathrm{E} \mathrm{m}^{-2} \mathrm{~s}^{-1}$ (full sunlight, $\mu \mathrm{E}=\mu \mathrm{mol}$ photons) and on average, a daily dosage of $60 \mathrm{~mol}$ photons $\mathrm{m}^{-2}$ is reached (Melis et al., 1998). Cyanobacteria like Limnospira spp. are very potent $\mathrm{O}_{2}$ producers. For example, ponds in southeastern California release about $16.8 \mathrm{t}$ of $\mathrm{O}_{2} \mathrm{ha}^{-1} \mathrm{yr}^{-1}$ while fixating $6.9 \mathrm{t}$ of $\mathrm{CO}_{2} \mathrm{ha}^{-1} \mathrm{yr}^{-1}$.

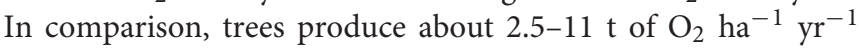
and fixate 1-4 $\mathrm{t}$ of $\mathrm{CO}_{2} \mathrm{ha}^{-1} \mathrm{yr}^{-1}$ (Henrikson, 2010). It has been found, that Limnospira cultures are about 2.5 times more productive in tropical environments and under these warm and humid conditions, a pond surface of approximately $80 \mathrm{~m}^{2}$ would meet the oxygen needs of one crew member. It was stated that the use of modern photobioreactors that e.g., control temperature, humidity, $\mathrm{CO}_{2}$ influx and illumination could reduce the needed surface significantly (Verseux et al., 2015).

In BIOS-I, the experimental data proposed that $20 \mathrm{~L}$ or respectively, an illuminated surface of $8 \mathrm{~m}^{2}$ of Chlorella culture is needed to supply one crew member. In comparison, the BIOS3 experiment investigated how big a plant compartment has to be to sufficiently provide oxygen for one human and found that the surface would need to be $30 \mathrm{~m}^{2}$ (Gitelson, 1992). Javanmardian and Palsson (1992) showed that a 200 L PBR (calculated from a $600 \mathrm{~mL}$ prototype) containing Chlorella vulgaris is able to meet the gas exchange needs of one human and they proposed that the system could be downsized to a 20 L Chlorella vulgaris tank reactor if equipped with an optimized illumination system and regime. In addition, it was shown and experimentally demonstrated that the $\mathrm{O}_{2}$ production and $\mathrm{CO}_{2}$ consumption of a $83 \mathrm{~L} \mathrm{PBR}$ with Limnospira indica is adaptable via the light intensity and can meet the needs of a three rat compartment $(\sim 5-$ $10 \%$ of the $\mathrm{O}_{2}$ requirements of one human) in the MELiSSA Pilot Plant facility at the Universitat Autònoma de Barcelona. In this experiment, the rats were kept alive for several months through gas exchange with the PBR (Alemany et al., 2019).

\section{Biomass Production}

Algae and cyanobacteria are also more efficient for edible biomass production in many cases, as they need less surface or volume for biomass production than higher plants, can be continuously harvested, and are fully comestible without complex food preparation and with reduced waste production. Wheeler et al. (2003) presented biomass productivity data (edible dry weight biomass per area and day) of different plants and showed that wheat plants are able to produce up to $12.6 \mathrm{~g} \mathrm{~m}^{-2}$ $\mathrm{d}^{-1}$ and soybeans up to $6 \mathrm{~g} \mathrm{~m}^{-2} \mathrm{~d}^{-1}$. In comparison, in open ponds, Limnospira indica yields up to $15 \mathrm{~g} \mathrm{~m}^{-2} \mathrm{~d}^{-1}$ (dry weight) (Jimenez et al., 2003) and Spirulina sp. LEB-18 can yield up to $69 \mathrm{~g} \mathrm{~m}^{-2} \mathrm{~d}^{-1}$ (dry weight) (Morais et al., 2009). Helisch et al. (2020) also reported high biomass production rates (1.3 $\mathrm{g} \mathrm{L}^{-1} \mathrm{~d}^{-1}$ (dry weight per volume and day) for Chlorella vulgaris in a microgravity capable PBR (see Table 1, 
TABLE 1 | PBR ground experiments with the eukaryotic algae Chlorella vulgaris.

\begin{tabular}{|c|c|c|c|c|c|c|c|}
\hline Hardware & Gas exchange & Volume & Light intensity & Mode & Duration & Results & Authors \\
\hline PBR & $\begin{array}{l}\text { Hollow fiber } \\
\text { cartridges }\end{array}$ & $600 \mathrm{~mL}$ & $\begin{array}{l}0.6 \mathrm{~mW} / \mathrm{cm}^{2} \\
\text { (usable light) } \approx \\
27.6 \mu \mathrm{E} \mathrm{m}^{-2} \mathrm{~s}^{-1}\end{array}$ & $\begin{array}{l}\text { Batch and } \\
\text { continuous }\end{array}$ & $>2$ months & $\begin{array}{l}\text { The measured oxygen } \\
\text { production rate under } \\
\text { continuous operation } \\
\text { (4-6 mmol/L*h) meets the } \\
\text { expectations }\end{array}$ & $\begin{array}{l}\text { Javanmardian } \\
\text { and Palsson } \\
(1992)\end{array}$ \\
\hline $\begin{array}{l}\text { PBR with a vertical } \\
\text { rectangular } \\
\text { slab-shaped } \\
\text { illumination } \\
\text { chamber }\end{array}$ & $\begin{array}{l}\text { Hollow fiber } \\
\text { cartridges }\end{array}$ & $\begin{array}{l}\text { 70-340 mL, } \\
\text { depending on } \\
\text { the experiment } \\
\text { and the number } \\
\text { of illumination } \\
\text { chambers }\end{array}$ & $\begin{array}{l}25 \mathrm{~mW} / \mathrm{cm}^{2} \text { (on } \\
\text { each LED plate) } \approx \\
1,150 \mu \mathrm{E} \mathrm{m}^{-2} \mathrm{~s}^{-1} \\
\text { via LED }\end{array}$ & Continuous & 10 days & $\begin{array}{l}\text { The general performance of the } \\
\text { hollow fiber PBR was } \\
\text { comparable to the PBR using a } \\
\text { sparging system, but the } \\
\text { oxygen production rate was } \\
\text { decreased }\end{array}$ & $\begin{array}{l}\text { Lee and } \\
\text { Palsson (1995) }\end{array}$ \\
\hline $\begin{array}{l}\text { Plate PBR with } \\
\text { automated control } \\
\text { system }\end{array}$ & Unknown & $1.5 \mathrm{~L}$ & $\begin{array}{l}2 \text { LED panels with } \\
117- \\
143 \mu \mathrm{E} \mathrm{m}^{-2} \mathrm{~s}^{-1}\end{array}$ & Continuous & 6 months & $\begin{array}{l}\text { A completely closed water } \\
\text { cycle could be achieved in the } \\
\text { biological system containing } \\
\text { multiple organisms. A sufficient } \\
\text { gas exchange was also } \\
\text { achieved. }\end{array}$ & $\begin{array}{l}\text { Tong et al. } \\
(2011,2012)\end{array}$ \\
\hline $\begin{array}{l}\text { Plate PBR with } \\
\text { automated control } \\
\text { system }\end{array}$ & Unknown & $1.5 \mathrm{~L}$ & $\begin{array}{l}150,300, \text { and } \\
350 \mu \mathrm{E} \mathrm{m}^{-2} \mathrm{~s}^{-1}\end{array}$ & Continuous & 192 days & $\begin{array}{l}\text { C. vulgaris can be used as an } \\
\text { emergency system in case of } \\
\text { high plant system problems. } \\
\text { Additionally, the } \mathrm{CO}_{2} \text { and } \mathrm{O}_{2} \\
\text { concentrations could be kept in } \\
\text { a good range. }\end{array}$ & Li et al. (2013) \\
\hline Raceway PBR & $\begin{array}{l}\text { Microgravity- } \\
\text { capable } \\
\text { membrane }\end{array}$ & $650 \mathrm{~mL}$ & $\begin{array}{l}200- \\
300 \mu \mathrm{E} \mathrm{m}^{-2} \mathrm{~s}^{-1}\end{array}$ & $\begin{array}{l}\text { Repeated } \\
\text { batch mode }\end{array}$ & 188 days & $\begin{array}{l}\text { Achievement of biomass } \\
\text { growth up to a maximum of } \\
12.2 \mathrm{~g} / \mathrm{l} \text {. The bioreactor works } \\
\text { on Earth and is ready to be } \\
\text { tested in Space (PBR@LSR) }\end{array}$ & $\begin{array}{l}\text { Helisch et al. } \\
(2020)\end{array}$ \\
\hline
\end{tabular}

light intensity: 200-300 $\mu \mathrm{E} \mathrm{m}^{-2} \mathrm{~s}^{-1}$ ). In addition, Zhang et al. (2018) observed generation times between 13 and $28 \mathrm{~h}$ for several cyanobacterial species at a light intensity of $30 \mu \mathrm{E} \mathrm{m} \mathrm{m}^{-2} \mathrm{~s}^{-1}$. Therefore, harvesting can be done continuously or several times a week, even under low light intensities. On the other hand, typical staple crop plants like rice, wheat or potato, usually take several months until they are harvestable (Watson et al., 2018). In fact, there are large discrepancies between the reported biomass volumetric productivities values. This is due to the fact that microalgae cultures are generally limited by light energy supply so that the production rate depends on the illuminated surface and the light intensity. Therefore, the productivities primarily depend on culture design (illuminated surface versus culture volume) and operational variable (light energy flux). A departure value of light energy yield by photosynthetic systems is in the order of magnitude of $20 \mathrm{~mol}$ of photons per mol of carbon fixed (Cornet and Dussap, 2009; Poughon et al., 2020). This is consistent with the maximum value of $69 \mathrm{~g} \mathrm{~m}^{-2} \mathrm{~d}^{-1}$ reported by Morais et al. (2009) with a maximum possible light intensity before the appearance of photo inhibition.

\section{Use of Biomass as Food Supplement}

Also, the full biomass of several microalgae is edible producing no waste like non-edible roots, stems or leaves. For example, the algae Chlorella vulgaris is rich in protein (up to 58\%) and contains all essential amino acids (Becker, 2007). It is also rich in unsaturated fatty acids, carotenoids, dietary fibers, vitamins, and minerals (Safi et al., 2014). The cyanobacterium Limnospira is also known for its great nutritive value including proteins of high quality, many minerals, vitamins and phytopigments (Farag et al., 2015). It was shown by Morist et al. (2001) that Limnospira indica can be used to produce healthy and nutritious food using different methods like freeze-drying, spray-drying and pasteurization. In addition, the consumption of Limnospira has beneficial features for space travelers because of its antioxidant and anti-inflammatory treats (Wu et al., 2016). Furthermore, it was shown that Limnospira indica is highly irradiation resistant (survival up to at least 6400 Gy of gamma rays) and therefore no negative effects from the increased ionizing irradiation in space are to be expected (Badri et al., 2015).

As algae and cyanobacteria can be cultivated axenic or defined xenic in bioreactors, they do not contribute possibly harmful microorganisms to the microbiome of a spacecraft (Helisch et al., 2020). In comparison, several crops need parts of their own microbiome for optimal growth and contain a risk of catching molds, when grown in spacecraft simulations (Saleem et al., 2019; Fahrion et al., 2020).

Despite the many advantages, using cyanobacteria and algae also has some disadvantages. For instance, cyanobacteria and algae contain less fiber then the edible biomass of plants and too few carbohydrates for a complete diet (Lehto et al., 2006). The nucleic acid content is too high in some microorganisms and some are also too high in certain minerals, which can have a negative effect on the health of the crew members (Averner et al., 1984). Lastly, nutrition from algae and cyanobacteria alone 
also has a negative impact on certain social aspects. Because photosynthetic microorganisms are very nutrient dense, only a few grams are usually ingested. Preparing, consuming and sharing food is impaired in this case, however, it was shown that the social aspect of eating is important for our mental and physical well-being (Chappuis et al., 2020). Furthermore, being around plants has a positive effect on the mental wellbeing of humans (Lehto et al., 2006). Ideally, a system connecting both should be aimed for as combining a cyanobacterial or algae PBR with a higher plant compartment increases the variety of the consumed food and was also shown to increase the recycling rates of a BLSS, and will also provide system redundancy for the essential $\mathrm{CO}_{2}$ removal and $\mathrm{O}_{2}$ production for the crew members (Gros et al., 2003).

\section{DEVELOPMENT OF BIOLOGICAL AIR REVITALIZATION SYSTEMS FOR SPACE}

The development of biological air revitalization in space is a tedious process. Even before a bioreactor is functional, several key aspects need to be addressed. One of the first tests is to investigate whether the target organism is able to survive a space upload, exposure and return. Different space exposure experiments were launched to address questions of survivability and resistance mechanisms of terrestrial microorganisms to microgravity and ionizing irradiation (Sancho et al., 2007; Onofri et al., 2012; de Vera et al., 2019). Additionally, the organisms are investigated for their growth kinetics, metabolic pathways and genetic stability, in engineered and space cultivation conditions. These primal experiments usually use liquid batch cultures. In a next step, a suitable kinetic model for all important parameters (e.g., in the case of cyanobacteria: $\mathrm{O}_{2}$ production, $\mathrm{CO}_{2}$ uptake, biomass production, use of nutrients, etc.) has to be developed and tested (Poughon et al., 2020). Only if the organism suits all requirements, experiments with fed-batch or continuous liquid cultures can start. For these tests, suitable PBR hardware has to be created. Sterility, biocompatibility, sealing and proper mixing are some of the requirements here. In addition, sufficient pumps for nutrient delivery and removal of biomass and products are needed (Ai et al., 2008). Depending on the organism, different $\mathrm{pH}$, temperature and nutrient control systems have to be installed. For phototrophic organisms, adequate illumination and gas transfer is necessary. Typically, specific membranes are used frequently to improve the transfer of gasses like $\mathrm{CO}_{2}$ and $\mathrm{O}_{2}$ to and from the liquid phase (Sarbatly and Suali, 2013).

As soon as a bioreactor and its control system are set up, the interconnection to other compartments of the BLSS has to follow.

\section{Development of Space PBRs on Earth}

Most of the research for biological air revitalization is executed on Earth. Tables 1-3 give an overview of the different ground experiments that were performed in the last 30 years for the development of PBRs for $\mathrm{O}_{2}$ production with Chlorella vulgaris, Limnospira indica and microalgae in combination with nitrifying communities providing the necessary nitrogen source for algal growth. The hardware and conditions that were used and the corresponding achievements are shown. The volumes for the experiments with Chlorella vulgaris were in lab scale and range between $70 \mathrm{~mL}$ and $1.5 \mathrm{~L}$. Different PBR shapes were used, and several interesting discoveries were made. Javanmardian and Palsson (1992) showed that the calculated $\mathrm{O}_{2}$ production and growth rate fits the experimental value and Li et al. (2013) concluded that a Chlorella vulgaris $\mathrm{PBR}$ can be used as an emergency $\mathrm{O}_{2}$ production system, in case of failure of a plant unit. Four of the five experiments shown in Table 1 persisted for over 2 months. Therefore, longer durations were covered, especially when compared to the experiments in Table 2 . The ground experiments with Limnospira indica in continuous mode were mainly conducted in cylindrical PBR. With exception of the experiment described in Farges et al. (2009), only the batch cultures were grown in rectangular flasks or Erlenmeyers. Models and their application to the set up were investigated in several experiments. For example, Alemany et al. (2019) validated a model for a two-compartment system and Cornet and Dussap (2009) tested the functionality of different hardware setups and defined a model to predict the $\mathrm{O}_{2}$ and biomass productivities of Limnospira indica. Table 3 displays three experiments using an interconnected system of nitrifying compartments to microalgae. It is an important step in the development of a functional BLSS to use nitrified urine as nitrogen source for algae and cyanobacteria. In an already quite sophisticated approach, Gòdia et al. (2002) showed the successful combination of a nitrifying bioreactor with a PBR containing Limnospira indica. The two other experiments showed that microalgae can be grown successfully on different nitrogen sources.

The bioreactors developed for space used artificial light (e.g., halogen lamps or LEDs) with varying intensities and different designs of hardware were used, e.g., plate, cylindrical and rectangular bioreactor forms (Tables 1-3). The volumes used are generally in lab to pilot scale and range from $100 \mathrm{~mL}$ (Cornet and Dussap, 2009) up to 83 L (Alemany et al., 2019). Batch as well as continuous modes were tested. Also, the durations of the experiments vary widely (a few hours up to 4 years). Limnospira indica was the most often used organism in these experiments (Table 2). In many experiments, the gas exchange between the liquid and gaseous phase was accomplished by airlift systems. However, due to minimal gravity in space, this aeration system does not work and has to be replaced by e.g., membraneaerated hardware (Wagner et al., 2015). Literature research revealed additional PBR research for space applications with other microorganisms. One interesting example is the ModuLES project with the green alga Chlamydomonas reinhardtii grown in a membrane-aerated plate-type PBR. Two liters of culture were grown continuously and the system was successfully tested in two parabolic flight campaigns (Wagner et al., 2015).

Additionally, many experiments using higher plants as photosynthetic organisms have been done, but these approaches are not covered in these tables.

\section{Testing Space PBRs in Space Flight}

So far, micro-gravity experiments in space only contributed small parts to the development of different life support systems. Space experiments are very expensive, need extensive 
TABLE 2 | PBR ground experiments with Limnospira indica.

\begin{tabular}{|c|c|c|c|c|c|c|c|}
\hline Hardware & $\begin{array}{c}\text { Gas } \\
\text { exchange }\end{array}$ & Volume & Light intensity & Mode & Duration & Results & Authors \\
\hline $\begin{array}{l}\text { Batches: } \\
\text { rectangular PBR, } \\
\text { cont.: cylindrical } \\
\text { PBR }\end{array}$ & Airlift & $\begin{array}{l}\text { Batches: } 1 \mathrm{~L} \text { and } \\
4 \mathrm{~L} \text {, cont.: } 7 \mathrm{~L}\end{array}$ & $\begin{array}{l}\text { Batch: via white } \\
\text { fluorescent lamps } \\
\text { (20 W), continuous: via } \\
\text { halogen lamps (20 W) }\end{array}$ & $\begin{array}{l}\text { Batch and } \\
\text { continuous }\end{array}$ & Unknown & $\begin{array}{l}\text { A model to couple radiant } \\
\text { light transfer and growth } \\
\text { kinetics is proposed }\end{array}$ & Cornet et al. (1995) \\
\hline $\begin{array}{l}\text { PBR, } 2 \text { identical } \\
\text { cylinders }\end{array}$ & $\begin{array}{l}\text { External loop } \\
\quad \text { airlift }\end{array}$ & $77 \mathrm{~L}$ & $\begin{array}{l}\text { Batch: } 95 \mathrm{~W} / \mathrm{m}^{2} \approx \\
\left.437 \mu \mathrm{E} \mathrm{m}^{-2} \mathrm{~s}^{-1}\right) \\
\text { cont.: } 133 \mathrm{~W} / \mathrm{m}^{2} \approx \\
\left.611.8 \mu \mathrm{E} \mathrm{m}^{-2} \mathrm{~s}^{-1}\right) \text { via } \\
\text { white halogen lamps } \\
(20 \mathrm{~W})\end{array}$ & $\begin{array}{l}\text { Batch and } \\
\text { continuous }\end{array}$ & $\begin{array}{c}400 \mathrm{~h} \\
\text { (16.66 days) }\end{array}$ & $\begin{array}{l}\text { Scaling up a } 7 \mathrm{~L} \text { to } 77 \mathrm{~L} \\
\text { PBR was successful and } \\
\text { the developed model was } \\
\text { applicable }\end{array}$ & $\begin{array}{l}\text { Vernerey et al. } \\
\text { (2001) }\end{array}$ \\
\hline $\begin{array}{l}\text { PBR, } 2 \text { identical } \\
\text { cylinders }\end{array}$ & $\begin{array}{l}\text { External loop } \\
\quad \text { airlift }\end{array}$ & $77 \mathrm{~L}$ & $\begin{array}{l}\text { Incident light flux } \\
133 \mathrm{~W} / \mathrm{m}^{2} \approx \\
\left.611.8 \mu \mathrm{E} \mathrm{m}^{-2} \mathrm{~s}^{-1}\right) \text { via } \\
\text { white halogen lamps } \\
(20 \mathrm{~W})\end{array}$ & Continuous & Unknown & $\begin{array}{l}\text { Three food preparation } \\
\text { methods can be used to } \\
\text { process } L \text {. indica to } \\
\text { constitute a safe food } \\
\text { source }\end{array}$ & Morist et al. (2001) \\
\hline Cylindrical PBR & Airlift & $5 \mathrm{~L}$ & 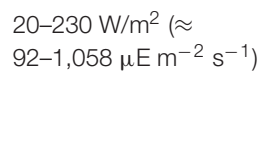 & Continuous & Unknown & $\begin{array}{l}\text { The metabolic network of } \\
\text { L. indica was characterized } \\
\text { and revealed some } \\
\text { interesting constraints }\end{array}$ & $\begin{array}{l}\text { Cogne et al. } \\
(2003 b)\end{array}$ \\
\hline Cylindrical PBR & $\begin{array}{l}\text { Mixing and } \\
\text { headspace }\end{array}$ & $132 \mathrm{~mL}$ & Via halogen lamp & Batch & Up to $400 \mathrm{~h}$ & $\begin{array}{l}\text { L. indica could be grown in } \\
\text { a newly designed PBR. } \\
\text { Pressure, pH, temperature } \\
\text { and cell density were } \\
\text { monitored online }\end{array}$ & Cogne et al. (2005) \\
\hline $\begin{array}{l}\text { Eight different } \\
\text { PBRs, different } \\
\text { volumes, shapes, } \\
\text { illumination }\end{array}$ & $\begin{array}{l}\text { Depending } \\
\text { on the PBR, } \\
\text { mostly aillift }\end{array}$ & $0.1-77 \mathrm{~L}$ & $\begin{array}{l}\text { Photon fluxes between } \\
30 \text { and } \\
1,600 \mu \mathrm{E} \mathrm{m}^{-2} \mathrm{~s}^{-1}\end{array}$ & $\begin{array}{l}\text { Batch and } \\
\text { continuous }\end{array}$ & $\begin{array}{l}\text { Cont. } \\
\text { cultures: at } \\
\text { least six } \\
\text { residence } \\
\text { times }\end{array}$ & $\begin{array}{l}\text { Successful presentation of } \\
\text { an analytical formula to } \\
\text { predict the productivities of } \\
\text { L. indica in different PBRs }\end{array}$ & $\begin{array}{l}\text { Cornet and Dussap } \\
\text { (2009) }\end{array}$ \\
\hline $\begin{array}{l}\text { Erlenmeyer flasks } \\
\text { (batch), cylindrical } \\
\text { PBR }\end{array}$ & Unknown & $250 \mathrm{~mL}$ and $2 \mathrm{~L}$ & $\begin{array}{l}43 \mu \mathrm{E} \mathrm{m}^{-2} \mathrm{~s}^{-1} \text { (batch), } \\
140 \mu \mathrm{E} \mathrm{m}^{-2} \mathrm{~s}^{-1} \text { (PBR) }\end{array}$ & $\begin{array}{l}\text { Batch and } \\
\text { continuous }\end{array}$ & $\begin{array}{l}\text { Up to } \\
50 \text { days } \\
\text { (PBR) }\end{array}$ & $\begin{array}{l}\text { Urea seems to be a better } \\
\text { nitrogen source than } \mathrm{NH}_{4}^{+} \text {. } \\
\text { Pulse feeding might help to } \\
\text { avoid inhibitory effects }\end{array}$ & $\begin{array}{l}\text { Deschoenmaeker } \\
\text { et al. (2017) }\end{array}$ \\
\hline $\begin{array}{l}\text { Cylindrical double } \\
\text { jacketed PBR }\end{array}$ & $\begin{array}{l}\text { Purging with } \\
\mathrm{N}_{2} \text {, stirring } \\
\text { with turbine }\end{array}$ & $2 \mathrm{~L}$ & $\begin{array}{l}60 \mu \mathrm{E} \mathrm{m}^{-2} \mathrm{~s}^{-1} \text { (batch) } \\
\text { and } \\
300 \pm 50 \mu \mathrm{E} \mathrm{m}^{-2} \mathrm{~s}^{-1} \\
\text { (PBR), radially } \\
\text { illuminated }\end{array}$ & $\begin{array}{l}\text { Batch and } \\
\text { continuous }\end{array}$ & 90 days & $\begin{array}{l}\mathrm{NH}_{4}{ }^{+} \text {salts (instead of } \\
\text { expensive } \mathrm{NO}_{3}-\text { salts) can } \\
\text { be used to commercially } \\
\text { grow } L \text {. indica }\end{array}$ & $\begin{array}{l}\text { Sachdeva et al. } \\
\text { (2018a) }\end{array}$ \\
\hline $\begin{array}{l}\text { Erlenmeyer flasks } \\
\text { (batch) and } \\
\text { cylindrical double } \\
\text { jacketed PBR }\end{array}$ & $\begin{array}{l}\text { Purging with } \\
\mathrm{N}_{2} \text {, stirring } \\
\text { with turbine }\end{array}$ & $\begin{array}{l}250 \mathrm{~mL} \text { (batch), } 2 \mathrm{~L} \\
\text { (PBR) }\end{array}$ & $\begin{array}{l}60 \mu \mathrm{E} \mathrm{m}^{-2} \mathrm{~s}^{-1} \text { (batch) } \\
\text { and } \\
300 \pm 50 \mu \mathrm{E} \mathrm{m}^{-2} \mathrm{~s}^{-1} \\
\text { (PBR), radially } \\
\text { illuminated }\end{array}$ & $\begin{array}{l}\text { Batch and } \\
\text { continuous }\end{array}$ & 7 days & $\begin{array}{l}\text { Demonstration of potential } \\
\text { of using urea and nitrite } \\
\text { salts, as cheaper } \\
\text { alternatives to nitrate salts }\end{array}$ & $\begin{array}{l}\text { Sachdeva et al. } \\
\text { (2018b) }\end{array}$ \\
\hline
\end{tabular}


TABLE 2 | Continued

\begin{tabular}{|c|c|c|c|c|c|c|c|}
\hline Hardware & $\begin{array}{c}\text { Gas } \\
\text { exchange }\end{array}$ & Volume & Light intensity & Mode & Duration & Results & Authors \\
\hline $\begin{array}{l}\text { PBR consisting } \\
\text { of two glass } \\
\text { cylindrical tubes }\end{array}$ & $\begin{array}{l}\text { External-loop } \\
\text { airlift }\end{array}$ & $\begin{array}{l}83 \mathrm{~L} \text { (55 L } \\
\text { illuminated volume) }\end{array}$ & $\begin{array}{l}\text { Varying depending on } \\
\text { experiment }\end{array}$ & Continuous & $\begin{array}{l}30 \text { and } \\
50 \text { days }\end{array}$ & $\begin{array}{l}\text { A mathematical model to } \\
\text { describe a two } \\
\text { compartment system is } \\
\text { successfully demonstrated. } \\
\text { ("crew" = rats and PBR } \\
\text { providing } \mathrm{O}_{2} \text { ) }\end{array}$ & $\begin{array}{l}\text { Alemany et al. } \\
(2019)\end{array}$ \\
\hline $\begin{array}{l}\text { Flat, cylindrical } \\
\text { PBR }\end{array}$ & Hollow fibers & $2.6 \mathrm{~L}$ & $\begin{array}{l}20,35, \text { and } 50 \mathrm{~W} / \mathrm{m}^{2} \\
(\approx 92,161, \\
\left.230 \mu \mathrm{E} \mathrm{m}^{-2} \mathrm{~s}^{-1}\right), \text { via } \\
\text { LED }\end{array}$ & Quasi-batch & 27 days & $\begin{array}{l}\text { No excessive shear stress } \\
\text { is applied to the bacteria, } \\
\text { the model is applicable }\end{array}$ & $\begin{array}{l}\text { Chapuis et al. } \\
(2020)\end{array}$ \\
\hline
\end{tabular}

TABLE 3 | PBR ground experiments on algae and cyanobacteria, fed by a nitrifying culture.

\begin{tabular}{|c|c|c|c|c|c|c|c|c|}
\hline Organisms & Hardware & $\begin{array}{l}\text { Gas } \\
\text { exchange }\end{array}$ & Volume & Light intensity & Mode & Duration & Results & Authors \\
\hline $\begin{array}{l}\text { Limnospira indica } \\
\text { PCC 8005, fed by } \\
\text { Nitrosomonas } \\
\text { europaea ATCC } \\
\text { 19178, Nitrobacter } \\
\text { winogradsky ATCC } \\
14123\end{array}$ & $\begin{array}{l}\text { PBR, } 2 \text { identical } \\
\text { cylinders }\end{array}$ & $\begin{array}{l}\text { External } \\
\text { loop airlift }\end{array}$ & $\begin{array}{l}7 \mathrm{~L} \text { and } \\
77 \mathrm{~L}\end{array}$ & $\begin{array}{l}\text { white halogen } \\
\text { lamps }(20 \mathrm{~W}) \\
\text { between } \approx \\
100-400 \mathrm{~W} / \mathrm{m}^{2}(\approx \\
460- \\
\left.1,840 \mu \mathrm{E} \mathrm{m}^{-2} \mathrm{~s}^{-1}\right)\end{array}$ & Continuous & $\begin{array}{l}4 \text { years, many } \\
\text { different } \\
\text { experiments } \\
\text { and conditions }\end{array}$ & $\begin{array}{l}\text { The separately operated as } \\
\text { well as the interconnected } \\
\text { bioreactors were successfully } \\
\text { run in a continuous way }\end{array}$ & $\begin{array}{l}\text { Gòdia et al. } \\
\text { (2002) }\end{array}$ \\
\hline $\begin{array}{l}\text { Axenic Limnospira } \\
\text { indica, fed by } 12 \\
\text { different nitrifying } \\
\text { inocula }\end{array}$ & $\begin{array}{l}\text { Two membrane } \\
\text { bioreactors } \\
\text { (nitrifying } \\
\text { community), } \\
\text { 96-well plate } \\
\text { (L. indica) }\end{array}$ & Air pump & $\begin{array}{c}8 \mathrm{~L} \\
\text { (bioreactor), } \\
0.3 \mathrm{~mL} \\
\text { (L. indica) } \\
\text { and } 0.8 \mathrm{~L} \\
\text { (L. indica) }\end{array}$ & $\begin{array}{l}200 \mu \mathrm{E} \mathrm{m}^{-2} \mathrm{~s}^{-1} \\
(0.3 \mathrm{~mL} \text { batch of } \\
\text { L. indica), } \\
160 \mu \mathrm{E} \mathrm{m}^{-2} \mathrm{~s}^{-1} \\
(0.8 \mathrm{~L} \text { batch of } \\
\text { L. indica) }\end{array}$ & $\begin{array}{l}\text { Batch and } \\
\text { continuous }\end{array}$ & $\begin{array}{l}0.8 L \text { batches } \\
\text { of } L . \text { indica: } \\
10 \text { days, } \\
\text { bioreactor up } \\
\text { to } 180 \text { days } \\
\text { (diagram) }\end{array}$ & $\begin{array}{l}\text { Limnospira indica grew with } \\
\text { high rates on the nitrified } \\
\text { urine and yielded a high } \\
\text { biomass protein content. } \\
\text { Nitrobacter spp. became the } \\
\text { dominant species in the nitrite } \\
\text { oxidizing community }\end{array}$ & $\begin{array}{l}\text { Coppens } \\
\text { et al. (2016) }\end{array}$ \\
\hline $\begin{array}{l}\text { Different microalgae } \\
\text { species, fed by } \\
\text { commercially } \\
\text { available nitrifying } \\
\text { activated sludge }\end{array}$ & $\begin{array}{l}\text { Plexiglas, } \\
\text { gastight PBR }\end{array}$ & Airlift & $4 \mathrm{~L}$ & $300 \mu \mathrm{E} \mathrm{m}^{-2} \mathrm{~s}^{-1}$ & $\begin{array}{l}\text { Semi- } \\
\text { continuous }\end{array}$ & 180 days & $\begin{array}{l}\text { The biological oxidation of all } \\
\text { nitrogen sources in urine was } \\
\text { successful and is a promising } \\
\text { treatment for nutrient } \\
\text { recovery of waste water }\end{array}$ & $\begin{array}{l}\text { Muys et al. } \\
(2018)\end{array}$ \\
\hline
\end{tabular}

preparation and the precious crew-time of astronauts (Leys et al., 2004). Nevertheless, some experiments on liquid culturing and photobioreactors have already been performed in space (Table 4). Depending on the scientific question, many different experimental setups were used, i.e., liquid cultivation using different tube and flask designs up to fully assembled bioreactors (Poughon et al., 2020). Most conducted experiments aimed for very fundamental questions like how liquid cultures respond to microgravity and space radiation. The earliest record for algae flown to space dates back to 1960. In this $25 \mathrm{~h}$ experiment on Korabl-Sputnik 2, the algae were grown on agar in the dark and in liquid culture under periodic artificial illumination. Since some cells survived the flight and were able to grow and reproduce, it was concluded that algae can perform their basic physiological and photosynthetic functions in orbit (Semenenko and Vladimirova, 1961). More elaborate experiments were conducted in the years afterward, using different photosynthetic organisms on space stations (Mir, ISS) and on free flying return capsules. In the 1960s, 1970s, and 1980s, common organisms were Chlorella pyrenoidosa, Chlorella vulgaris and Chlamydomonas reinhardtii (Niederwieser et al., 2018). In 1987, the cyanobacterium Nostoc sp. PCC7524 and a plastid mutant of the eukaryotic alga Euglena gracilis flew on board a Long
March II Chinese rocket to space. In this experiment, the plastid mutant alga was the $\mathrm{O}_{2}$ consumer and $\mathrm{CO} 2$ producer and the cyanobacterium produced $\mathrm{O}_{2}$ and consumed $\mathrm{CO}_{2}$, respectively. It could be shown, that both organisms survived the 4.5 days in space and that some of the cyanobacteria grew under illumination (Dubertret et al., 1987). The used hardware of this early experiment is shown in Figure 1. This experiment is often referred to as the origin of MELiSSA (Lasseur and Mergeay, 2021, accepted for publication). In the later years, there were also some approaches with cyanobacteria like Nostoc commune var. sphaeroides (Wang et al., 2004), Anabaena siamensis (Wang et al., 2006), and Limnospira indica (Ilgrande et al., 2019). The latter was used in the Arthrospira-B experiment which was launched to the ISS in 2017 and which was the first approach to allow online measurements of the $\mathrm{O}_{2}$ production rate as well as growth rate in space. Additionally, the cultures were kept axenic over the entire duration of over 1 month (Poughon et al., 2020). To date, this experiment is the most sophisticated successful approach to run an instrumented photobioreactor onboard a space station (Figure 1).

Although several experiments using photobioreactors in space were conducted, many of them were unsuccessful or the data were never reported in publications (Niederwieser et al., 2018). The 
TABLE 4 | PBR space flight experiments with algae and cyanobacteria ( last 30 years, only published ones, chronologically listed).

\begin{tabular}{|c|c|c|c|c|c|c|c|c|}
\hline Organism & Vehicle & Hardware & Volume & Light intensity & Mode & Duration & Results & Authors \\
\hline $\begin{array}{l}\text { Nostoc sp. } \\
\text { PCC7524 and a } \\
\text { plastid mutant of } \\
\text { Euglena gracilis }\end{array}$ & $\begin{array}{l}\text { Long March } \\
\qquad 2\end{array}$ & $\begin{array}{l}\text { Dialysis bags that } \\
\text { allow for gas } \\
\text { exchange }\end{array}$ & $\begin{array}{l}3 \text { mL per } \\
\text { culture }\end{array}$ & 0.3 W bulb & 1 batch & 4.5 days & $\begin{array}{l}\text { Fixation of the cells was } \\
\text { successful, some of the Nostoc } \\
\text { cells germinated in the } \\
\text { microgravity conditions }\end{array}$ & $\begin{array}{l}\text { Dubertret } \\
\text { et al. (1987) }\end{array}$ \\
\hline $\begin{array}{l}\text { Chlorella vulgaris } \\
\text { LARG-1 }\end{array}$ & $\begin{array}{c}\text { Bion-9 } \\
\text { (Cosmos, } \\
\text { 2044) }\end{array}$ & $\begin{array}{l}\text { Three- } \\
\text { component } \\
\text { aquatic system }\end{array}$ & Unknown & $\begin{array}{l}\text { Unknown, but it } \\
\text { was illuminated }\end{array}$ & 1 batch & 13 days & $\begin{array}{l}\text { Microscopy revealed } \\
\text { differences in } \\
\text { organelle-organization between } \\
\text { space and ground samples but } \\
\text { there was so significant } \\
\text { difference in growth }\end{array}$ & $\begin{array}{l}\text { Popova } \\
\text { et al. (1989) }\end{array}$ \\
\hline $\begin{array}{l}\text { Nostoc } \\
\text { sphaeroides Kütz }\end{array}$ & Shenzhou-II & Closed chambers & $85 \mathrm{~mL}$ & $\begin{array}{l}\text { 2,200 Lux, 12-h- } \\
\text { dark/12-h-light } \\
\text { cycle }\end{array}$ & 1 batch & 6 days $15 \mathrm{~h}$ & $\begin{array}{l}\text { A high growth rate was } \\
\text { observed for the space } \\
\text { samples exposed to } \\
\text { microgravity }\end{array}$ & $\begin{array}{l}\text { Wang et al. } \\
\text { (2004) }\end{array}$ \\
\hline $\begin{array}{l}\text { Anabaena } \\
\text { siamensis FACHB } \\
799\end{array}$ & $\begin{array}{l}\text { Chinese } \\
\text { retrievable } \\
\text { satellite }\end{array}$ & small bioreactor & $200 \mathrm{~mL}$ & $15 \mu E m^{-2} s^{-1}$ & 1 batch & 15 days & $\begin{array}{l}\text { Growth in space was slower, } \\
\text { but after return, the space } \\
\text { cultures grew at a higher rate. } \\
\text { After a few generations, both } \\
\text { cultures grew at the same rate }\end{array}$ & $\begin{array}{l}\text { Wang et al. } \\
(2006)\end{array}$ \\
\hline $\begin{array}{l}\text { Euglena gracilis } \\
\text { with Oreochromis } \\
\text { mossambicus } \\
\text { (cichlid fish) }\end{array}$ & Foton M2 & $\begin{array}{l}\text { Cylindrical } \\
\text { prototype with } \\
\text { two connected } \\
\text { bioreactors }\end{array}$ & $\begin{array}{c}1.45 \mathrm{~L} \\
\text { (E. gracilis) } \\
\text { and } 1.26 \mathrm{~L} \\
\text { (fish) }\end{array}$ & $\begin{array}{l}\text { Via red LEDs } \\
\text { (emission peak at } \\
625 \mathrm{~nm} \text { ) }\end{array}$ & Continuous & 15 days & $\begin{array}{l}\text { The oxygen production of } \\
\text { E. gracilis gradually decreased } \\
\text { in the first } 9 \text { days and increased } \\
\text { afterward. Seven of the } 35 \text { fish } \\
\text { died }\end{array}$ & $\begin{array}{l}\text { Häder et al. } \\
\text { (2006) }\end{array}$ \\
\hline $\begin{array}{l}\text { Chlorella } \\
\text { pyrenoidosa } \\
\text { FACHB } 415 \text { and } \\
\text { Bulinus australianus } \\
\text { (snail) }\end{array}$ & $\begin{array}{l}\text { Chinese } \\
\text { retrievable } \\
\text { satellite and } \\
\text { Shenzhou-॥ }\end{array}$ & Culture chambers & $\begin{array}{l}85 \mathrm{~mL} \text { algal } \\
\text { culture in } \\
120 \mathrm{~mL} \\
\text { chamber }\end{array}$ & $35 \mu \mathrm{E} \mathrm{m}^{-2} \mathrm{~s}^{-1}$ & 1 batch & $\begin{array}{l}\text { Satellite: } \\
15 \text { days; } \\
\text { spacecraft: } \\
6 \text { days } 15 \text { h }\end{array}$ & $\begin{array}{l}\text { Satellite: The algae survived but } \\
\text { became a little lower in number, } \\
\text { the snails died (probably from } \\
\mathrm{CO} 2 \text { intoxication), spacecraft: } \\
\text { the average Chlorella } \\
\text { concentration decreased }\end{array}$ & $\begin{array}{l}\text { Wang et al. } \\
(2008)\end{array}$ \\
\hline $\begin{array}{l}\text { Euglena gracilis } \\
\text { with Oreochromis } \\
\text { mossambicus } \\
\text { (cichlid fish) }\end{array}$ & Foton M3 & $\begin{array}{l}\text { Polycarbonate } \\
\text { cylinder with } \\
\text { adjacent } \\
\text { compartments }\end{array}$ & Unknown & $\begin{array}{l}\text { Via three pairs of } \\
\text { high-power red } \\
\text { LEDs }\end{array}$ & Continuous & 12 days & $\begin{array}{l}\text { The oxygen level in the tank } \\
\text { decreased a little more than } \\
\text { expected. } 11 \text { out of } 26 \text { fishes } \\
\text { survived the flight }\end{array}$ & $\begin{array}{l}\text { Strauch } \\
\text { et al. (2008) }\end{array}$ \\
\hline Euglena gracilis Z & Shenzhou-8 & $\begin{array}{l}\text { Double culture } \\
\text { chamber, } \\
\text { separated by } \\
\text { biofoil }\end{array}$ & $11 \mathrm{~mL}$ & $500 \mu \mathrm{Em}^{-2} \mathrm{~s}^{-1}$ & 1 batch & $\begin{array}{l}17 \text { days, } \\
\text { fixation after } \\
40 \text { min (other } \\
\text { samples } \\
\text { failed) }\end{array}$ & $\begin{array}{l}\text { First report on } \\
\text { microgravity-induced changes } \\
\text { at the transcriptional level of an } \\
\text { unicellular eukaryotic organism }\end{array}$ & $\begin{array}{l}\text { Nasir et al. } \\
\text { (2014), } \\
\text { Preu and } \\
\text { Braun } \\
\text { (2014) }\end{array}$ \\
\hline $\begin{array}{l}\text { Limnospira indica } \\
\text { PCC8005 }\end{array}$ & ISS & $\begin{array}{l}\text { Cylindrical PBR } \\
\text { with flat } \\
\text { membrane liquid } \\
\text { and gaseous } \\
\text { phase }\end{array}$ & $60 \mathrm{~mL}$ & $\begin{array}{l}35 \text { and } 45 \mu \mathrm{E} \\
\mathrm{m}^{-2} \mathrm{~s}^{-1}\end{array}$ & $\begin{array}{c}\text { Batches } \\
(14,6,8 \\
6 \text { days })\end{array}$ & 5 weeks & $\begin{array}{l}\text { Generally successful, but some } \\
\text { technical difficulties. First } \\
\text { dynamic growth of } \\
\text { cyanobacteria in space and the } \\
\text { gas and biomass model was } \\
\text { shown to be applicable }\end{array}$ & $\begin{array}{l}\text { Poughon } \\
\text { et al. (2020) }\end{array}$ \\
\hline
\end{tabular}

first experiment with in-flight analysis on Chlorella sorokiniana in liquid medium for 30 days failed because the reactor had a leak and exposed the algae to vacuum (Ward et al., 1970). A more recent unsuccessful experiment is the Eu:CROPIS project described in Hauslage et al. (2018). In this life support system experiment, Euglena gracilis was used in combination with a tomato plant and different bacteria (Nitrosomonas, Nitrobacter) to produce $\mathrm{O}_{2}$ and edible biomass. Unfortunately, the flight experiment did not result in usable data due to a technical failure. Another example is the PBR@LSR project. In this project, a PBR inoculated with Chlorella vulgaris was brought to the ISS in 2019. The proposed experiment time was 6 months, but the experiment had to be terminated after a few weeks due to technical issues
(Keppler et al., 2018). Table 4 shows a selection of space flight experiments using photosynthetic unicellular organisms in illuminated test chambers (PBRs) that have been in space over the last 30 years. Since not all of the experiments in space have been successful, not all space experiments were published so that only experiments published in peer reviewed papers that could be used as references are shown.

\section{DISCUSSION}

In this section, we highlight the different challenges in context of PBR for space applications in order to give an overview of 

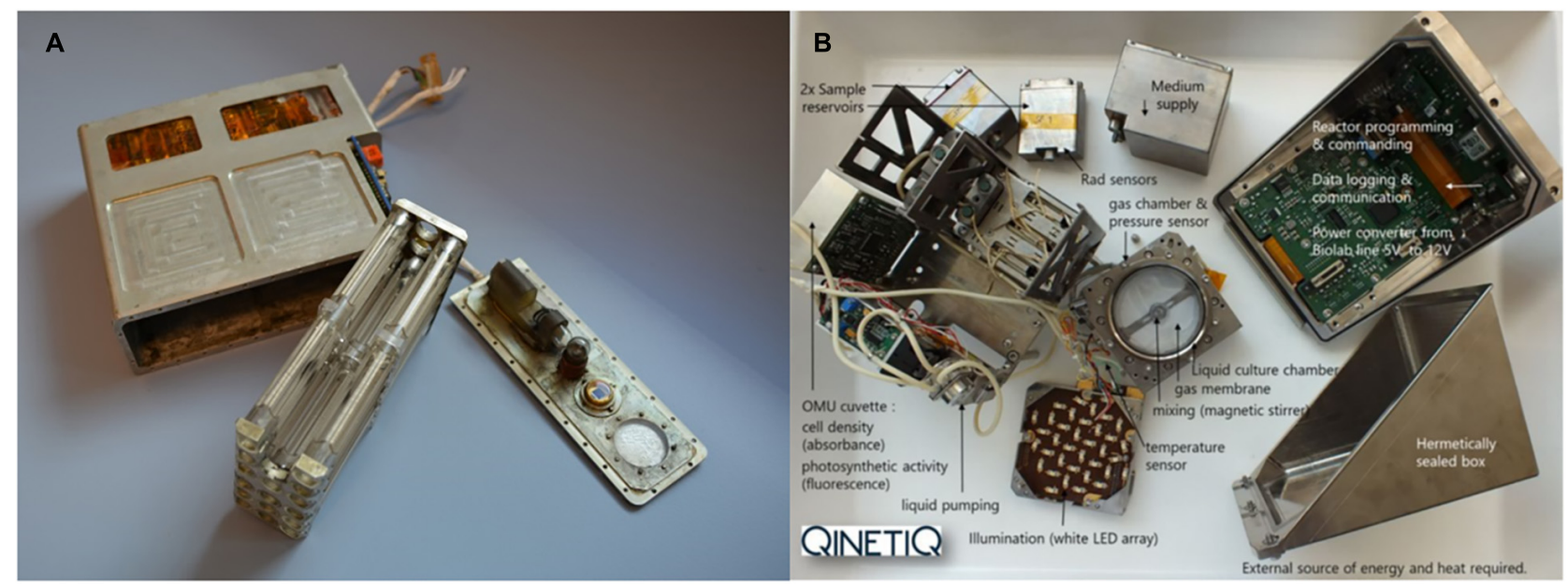

FIGURE 1 | (A) Nostoc sp./Euglena gracilis container of the first space flight experiment associated with MELiSSA (Dubertret et al., 1987), courtesy of ESA. (B) Limnospira indica hardware from the ArtEMISS-B experiment (Poughon et al., 2020, original source: QINETIQ).

knowledge gaps and problems that already occurred or might arise in the future of BLSS research.

\section{Safety and Reliability - Robustness, Resilience, and Redundancy}

The safety and reliability of a life support system is of utmost importance. In order to avert fatal incidents, several backup facilities and control mechanisms have to be installed and the system has to be monitored consistently. All possible scenarios have to be calculated and evaluated beforehand to avoid failure, because failure can be fatal for the crew (Bartsev et al., 1996). For example, a failure in $\mathrm{O}_{2}$ production has to be intercepted by an emergency system before a drop in the $\mathrm{O}_{2}$ concentration of the cabin occurs. A high degree of redundancy has to be achieved. Physicochemical emergency back-up systems, plant compartments and different PBRs could be put in parallel that can be uncoupled from each other. And not all bioreactors need to be operated in long duration continuous production, but a regime of alternating batches or operation and downtime of bioreactors could be implemented, if shown to be advantageous for operation, harvesting or maintenance. In addition, reliable mathematical models for the bioreactors are essential to keep all processes predictable (Vernerey et al., 2001). This is a highly strategic point when the recycling efficiencies of different elements and compounds are coupled and intertwined as it is the case for BLSS, such as MELiSSA. In this case, the action on an operational variable has distributed consequences at several points of the recycling system, calling for an intelligent control strategy based on knowledge models taking into account the dynamic exchanges between the different parts of the recycling system. The other important point for life support systems for space is that the buffer tanks generally have a minimal capacity entailing an online control strategy. The criteria for reliability, availability, maintainability and supportability (RAMS) engineering have to be applied in the BLSS research.

\section{Gas Exchange and $\mathrm{O}_{2} / \mathrm{CO}_{2}$ Balance Between Consumer and Producer}

As mentioned, on average, one human needs $\sim 0.82 \mathrm{~kg}$ of $\mathrm{O}_{2}$ and produces $\sim 1.04 \mathrm{~kg}$ of $\mathrm{CO}_{2}$ per day. Depending on the activity level, the ratio of exhaled $\mathrm{CO}_{2}$ to consumed $\mathrm{O}_{2}$, i.e., the respiratory coefficient, can vary (Anderson et al., 2018). On the other hand, the $\mathrm{O}_{2}$ production of algae and cyanobacteria can be characterized by a photosynthetic coefficient, describing the ratio of produced moles of $\mathrm{O}_{2}$ per consumed moles of $\mathrm{CO}_{2}$. This ratio is dependent on the organism (and its biochemical composition) and the nutrient substrate (e.g., the nitrogen source). The stoichiometric eqs. 3, 4 [simplified from Cornet et al. (1998)] show this dependence for Limnospira indica on the examples ammonium $\left(\mathrm{NH}_{3}\right)$ and nitrate $\left(\mathrm{NO}_{3}{ }^{-}\right.$or here: $\left.\mathrm{HNO}_{3}\right)$ as nitrogen sources. Solving the stoichiometric equations reveals that the photosynthetic coefficient for ammonium is $\sim 1.0$ and for nitrate $\sim 1.4$.

$$
\begin{aligned}
\mathrm{CO}_{2}+0.528 \mathrm{H}_{2} \mathrm{O}+0.173 \mathrm{NH}_{3}+n h \nu & \rightarrow \mathrm{CH}_{1.575} \mathrm{O}_{0.459} \mathrm{~N}_{0.173} \\
+ & 1.034 \mathrm{O}_{2} \\
\mathrm{CO}_{2}+0.701 \mathrm{H}_{2} \mathrm{O}+0.173 \mathrm{HNO}_{3}+n h \nu & \rightarrow \mathrm{CH}_{1.575} \mathrm{O}_{0.459} \mathrm{~N}_{0.173} \\
+ & 1.381 \mathrm{O}_{2}
\end{aligned}
$$

Importantly, it must be outlined that photosynthetic growth stoichiometry has no degree of freedom when the composition of nitrogen source (or its degree of reduction) is fixed so that the photosynthetic coefficient is only depending and linked to the culture conditions. The number of photons required to fix $1 \mathrm{~mol}$ of carbon is depending on the culture conditions. Away from photo inhibition conditions, a typical value is $n=20 \mathrm{~mol}$ photons per mol of carbon fixed (Cornet and Dussap, 2009; Poulet et al., 2020).

In order to avoid an imbalance in gas composition, a system has to be developed to combine the respiratory quotient of the crew members and the photosynthetic coefficient of the 
microalgae. In some experiments, successes were achieved (see section "Photosynthetic Microorganisms as Catalysers for Air Revitalization in Space"). However, gas exchange in space is much more complex, due to the lower or lack of gravity. There is still very little information about the gas, water and solute transport in microgravity in living organisms. Moreover, microgravity conditions strongly modify the environment of the chemical and biochemical processes, e.g., implying lack of sedimentation and impaired gas and liquid phase separation. Consequently, transport is limited to diffusion causing an increase of boundary layer thickness and therefore a significant decrease of mass and heat transfer coefficients. This can cause problems with pumping and the mineral availability for the cultures and has to be elucidated more thoroughly (Klaus et al., 1997).

\section{In situ Resource Utilization and Light as an Energy Source}

Another challenge is the complete closure of a BLSS. So far, no loop has an efficiency of $100 \%$, which means that all tested life support systems still rely on external addition of different substances like carbonate or trace elements, etc. For example, the 105 days long Lunar Palace 1 experiment (plants, insects, and three crew members) reached a full oxygen and water recycling but only $20.5 \%$ nitrogen recovery from urine and $55 \%$ of the food was regenerated. In this approach, physico-chemical and biological processes were combined (Fu et al., 2016). Some substances are either difficult to find in the space environment or it is very costly and time consuming to convert them into a usable form. Therefore, space habitats for humans have to be fully functional under the specific conditions and have to rely on the materials available around and only a small amount of material brought from Earth. For example, lunar regolith, mars soil and $\mathrm{CO}_{2}$ in the Martian atmosphere are promising substances to be used for in situ resource utilization (ISRU) (Montague et al., 2012; Muscatello and Santiago-Maldonado, 2012).

The usage of photoautotrophic organisms helps to overcome parts of the material problems because their main energy source is light. But so far, only experiments using artificial light (e.g., halogen lamps or LEDs) have been flown (Table 4) which means that the naturally available solar energy is not used directly so far. One of the main reasons is that the natural light intensities and spectral energy distributions available in space are not compatible with the needs of the photosynthetic organisms. The intensity of sun light depends on the distance from the sun and the irradiation spectrum in deep space consists of a different wavelength composition than the irradiation we experience on ground due to absorption of light in the Earth's atmosphere (Cockell and Horneck, 2001). Besides that, the ISS, Moon and Mars surface are eclipsed for $50 \%$ of the time and the day and night cycles, e.g., on the moon are very different from Earth. For example, one lunar night is as long as 18 Earth days (Alvarado et al., 2021; Xie et al., submitted) ${ }^{1}$. Also, the intensity

\footnotetext{
${ }^{1}$ Xie, G., Zhang, Y., Yang, J., Yu, D., Ren, M., Qiu, D., et al. (submitted). Adaptation to real 1/6 g Moon Gravity Contributes To Plant Development And Expeditious Acclimation To Super-Freezing. Chongqing, Research Square. doi: 10.1007/s00204016-1744-5
}

of natural light sources is much more difficult to be controlled than artificial light sources. Therefore, approaches where solar power is used to store energy in batteries as fuel for LEDs with suitable light characteristics, that can be used in PBRs and greenhouses, are desired.

\section{Scaling Up}

So far, the research on the PBR part of the BLSS is the most sophisticated area. But also in the PBR research, most experiments were done in lab up to pilot scale $(100 \mathrm{~mL}$ up to $83 \mathrm{~L}$, Tables 1-4) and these volumes were not sufficient to provide $100 \%$ of the $\mathrm{O}_{2}$ need of a crew member (Javanmardian and Palsson, 1992; Alemany et al., 2019). So even if a small lab scale bioreactor is successful, scaling-up procedures have to follow to achieve the needed production rates for a BLSS, which vary strongly depending on the used organisms (Vernerey et al., 2001). In order to develop a reliable system, the PBR needs to represent a well-balanced combination of a relatively small, but sufficient volume and high productivity via usage of proper illumination in high cell density cultures.

\section{Connecting Multiple Bioreactors and Closing the Loop}

Only a few experiments involve bioreactors that are connected to other life support compartments like the crew or a waste recycling compartment. Consequently, many challenges remain in this research area and the connection between the different systems has to be elucidated more. Additional experiments on the nitrifying community and the other parts of the waste treatment (e.g., thermophilic anaerobic bacteria to produce volatile fatty acids out of waste) have to be conducted in space and further developed on ground (Lasseur et al., 2010). Some unidentified problems might arise in connected bioreactors. Cross-contamination and cross-talking of the organisms by quorum sensing molecules between the different compartments might disturb the system on a long-term scale (Mastroleo et al., 2013). However, also in axenic bioreactors, there is missing knowledge about cell-cell communication and biofilm formation in space.

\section{Long Duration Cultivation in Engineered Bioreactors and Space Conditions}

The following question has to be answered: does a longterm cultivation in engineered bioreactors under space conditions have an effect on the microorganisms? A predictable and stable growth rate of the culture is essential for the performance of a PBR. Early stress signals have to be monitored to avoid culture failure in space and adequate countermeasures have to be developed. For this, low-dose prolonged irradiation and (simulated) microgravity experiments are needed. The genetic stability over multiple generations has to be addressed, e.g., the mutation rates, differences in gene expression and epigenetic effects like changes in DNA methylation patterns. So far, not enough experiments on long term conduction of photobioreactors were done, to answer that question. 
The effect of cosmic irradiation and reduced gravity on the oxygen production rate and nutritive value of the photosynthetic microorganisms has to be investigated. In plant experiments, it was reported that low doses of ionizing irradiation can cause an increase in growth rate (Sax, 1963; Upton, 2001), but for algae and cyanobacteria very limited data are available so far. Planel et al. (1987) presented a hormesis effect for the cyanobacterium Synechococcus lividus when irradiated with $1.49 \mathrm{mGy}$ per year. If proven for BLSS relevant organisms, such hormesis effects might even be useful for the BLSS productivity.

Most space experiments with living organisms have only been done in LEO so far. There are very few reports of microbial experiments that went out of LEO (Horneck et al., 2010). One of the rare examples is the Chinese lunar chang'e 4 lander that brought organisms (plants, yeast and fruit fly eggs) farther into Space (Xie et al., submitted, see text footnote 1). Therefore, future investigations need to be beyond LEO, and e.g., in Moon orbit or on the Moon surface. Also, insightful investigations remain to be systematically done in order to detail and understand the mechanisms of interaction of zero-gravity conditions and different levels of intracellular organization and metabolic regulation. By example, it is well-known that gravitropism is an important phenomenon for higher plants growth and roots development. Similar effects are likely to occur even in simpler prokaryotic organisms linked to dissolved gas exchanges (namely $\mathrm{O}_{2}$ and $\mathrm{CO}_{2}$ ) between intracellular level and the culture environment.

\section{Remote Commanding, Monitoring, Reporting, and Data Exploitation}

During literature research, it became apparent, that the published data often do not include all needed information. Especially the light intensity inside the culture, temperature and $\mathrm{pH}$ data are often missing.

Furthermore, the data of space experiments are deficient and often difficult to compare. For example, different sizes for different missions were used (Table 4) and the space experiments were mainly to investigate on exposure, survival and simplified processes. Also, only very few experiments with onboard monitoring can be found in the literature [e.g., ArtEMISSB described in Poughon et al. (2020)]. Real-time bioprocess monitoring has to be achieved to obtain reproducible and reliable results.

\section{REFERENCES}

Ai, W., Guo, S., Qin, L., and Tang, Y. (2008). 'Development of a ground-based space micro-algae photo-bioreactor’. Adv. Space Res. 41, 742-747. doi: 10.1016/j.asr. 2007.06.060

Alemany, L., Peiro, E., Arnau, C., Garcia, D., Poughon, L., Cornet, J. F., et al. (2019). 'Continuous controlled long-term operation and modeling of a closed loop connecting an air-lift photobioreactor and an animal compartment for the development of a life support system'. Biochem. Eng. J. 151:107323. doi: 10.1016/j.bej.2019.107323

Allen, J., and Nelson, M. (1997). 'Biospherics and Biosphere 2, mission one (1991-1993)'. Ecol. Eng. 13, 15-29. doi: 10.1016/s0925-8574(98)00 089-5

\section{CONCLUSION}

Bioregenerative life support systems are complex networks of biological and physicochemical transformations, including bioreactors, whose functioning are influenced by space environment like reduced gravity levels and increased doses of ionizing radiation. As a consequence, several biological and physical key bioreactor processes have to be controlled and adapted to these altered conditions by, for example, the usage of membrane-aerated PBRs. In practice, recent flown experiments have shown the challenge linked to the deployment of a successful PBR in space. Further knowledge is therefore needed to improve the necessary success rate that will allow continuous operation at a larger scale.

In general, more long-term continuous experiments should be conducted and all important parameters (temperature, gas exchange rates, light intensity, concentration of nutrients and biomass production) have to be monitored online, allowing remote bioreactor control from Earth, to reduce the dependence on the crew. Even though many promising experiments on photobioreactors for space applications were conducted, the development of a sufficient life support system still depends on an interconnected, continuously running loop system with a maximum closure.

\section{AUTHOR CONTRIBUTIONS}

JF and NL performed the literature research and writing of the first draft. FM, C-GD, and NL contributed to reviewing and editing. All authors contributed to the article and approved the submitted version.

\section{FUNDING}

This work was funded via the SCK CEN PHD Grant of Jana Fahrion, which is part of the ArtEMISS project funded by Belspo and ESA via the PRODEX program. The ArtEMISS project is part of the MELiSSA program of ESA.

\section{ACKNOWLEDGMENTS}

The authors would like to thank the MELiSSA consortium.

Alvarado, K. A., García Martínez, J. B., Matassa, S., Egbejimba, J., and Denkenberger, D. (2021). 'Food in space from hydrogen-oxidizing bacteria'. Acta Astronautica 180, 260-265. doi: 10.1016/j.actaastro.2020.12.009

Anderson, M. S., Ewert, M. K., and Keener, J. F. (2018). 'Life Support Baseline Values and Assumptions Document' Report Number NASA/TP-2015-218570/REV1.

Anderson, M. S., Macatangay, A. V., McKinley, M. K., Sargusingh, M. J., Shaw, L. A., Perry, J. L., et al. (2019). "NASA environmental control and life support technology development and maturation for exploration: 2018 to 2019 overview," in Proceeding of the 49th International Conference on Environmental Systems (Massachusetts).

Averner, M., Karel, M., and Radmer, R. (1984). Problems Associated With the Utilazation of Algae in Bioregenerative Life Support Systems, Durham:NH. New Hampshire University. 
Badri, H., Monsieurs, P., Coninx, I., Wattiez, R., and Leys, N. (2015). 'Molecular investigation of the radiation resistance of edible cyanobacterium Arthrospira sp. PCC 8005'. Microbiologyopen 4, 187-207. doi: 10.1002/mbo3.229

Bartsev, S.-I., Gitelson, J.-I., Lisovsky, G.-M., Mezhevikin, V.-V., and Okhonin, V.A. (1996). 'Perspectives of different type biological life support systems (BLSS) usage in space missions'. Acta Astronautica 39, 617-622. doi: 10.1016/s00945765(97)00012-x

Becker, E. W. (2007). 'Micro-algae as a source of protein'. Biotechnol. Adv. 25, 207-210. doi: 10.1016/j.biotechadv.2006.11.002

Chappuis, J., Pouwels, C.-R., Musilova, M., and Foing, B. (2020). "Personalised dietary plans and health effects on astronauts in extraterrestrial habitats," in Proceeding of the 51st Lunar and Planetary Science Conference.

Chapuis, D., Nebuloni, S., Dainesi, P., Laroche, C., Duchez, D., Dussap, C. G., et al. (2020). "Oxygen regeneration by algae cultivation in photo-bioreactor for iss cabin technology demonstrator," in Proceeding of the International Conference on Environmental Systems.

Cockell, C. S., and Horneck, G. (2001). 'The history of the UV radiation climate of the earth-theoretical and space-based observations'. Photochem. Photobiol. 73, 447-451. doi: 10.1562/0031-8655(2001)073<0447:thotur>2.0.co;2

Cogne, G., Cornet, J. F., and Gros, J. B. (2005). 'Design, operation, and modeling of a membrane photobioreactor to study the growth of the Cyanobacterium Arthrospira platensis in space conditions'. Biotechnol. Prog. 21, 741-750. doi: 10.1021/bp0495926

Cogne, G., Gros, J. B., and Dussap, C. G. (2003a). 'Identification of a metabolic network structure representative of Arthrospira (spirulina) platensis metabolism'. Biotechnol. Bioeng. 84, 667-676. doi: 10.1002/bit.10808

Cogne, G., Lehmann, B., Dussap, C. G., and Gros, J. B. (2003b). 'Uptake of macrominerals and trace elements by the cyanobacterium Spirulina platensis (Arthrospira platensis PCC 8005) under photoautotrophic conditions: culture medium optimization'. Biotechnol. Bioeng. 81, 588-593. doi: 10.1002/bit. 10504

Coppens, J., Lindeboom, R., Muys, M., Coessens, W., Alloul, A., Meerbergen, K., et al. (2016). 'Nitrification and microalgae cultivation for two-stage biological nutrient valorization from source separated urine'. Bioresour. Technol. 211, 41-50. doi: 10.1016/j.biortech.2016.03.001

Cornet, J.-F., Dussap, C. G., and Gros, J. B. (1998). "'Kinetics and energetics of photosynthetic micro-organisms in photobioreactors," in Bioprocess and Algae Reactor Technology, Apoptosis (Berlin: Springer).

Cornet, J.-F., Dussap, C. G., Gros, J.-B., Binois, C., and Lasseur, C. (1995). 'A simplified monodimensional approach for modeling coupling between radiant light transfer and growth kinetics in photobioreactors'. Chemical. Eng. Sci. 50, 1489-1500. doi: 10.1016/0009-2509(95)00022-w

Cornet, J.-F., and Dussap, C.-G. (2009). 'A Simple and Reliable Formula for Assessment of Maximum Volumetric Productivities in Photobioreactors. Hoboken, NJ: Wiley InterScience.

Crockett, A. J., Schermer, T. R., and Eston, R. G. (2018). 'Lung function 9'. Kinanthr. Exerc. Physiol. 1:225.

Daues, K. (2006). A History of Spacecraft Environmental Control and Life Support Systems. Washington, DC: NASA.

de Vera, J. P., Alawi, M., Backhaus, T., Baque, M., Billi, D., Bottger, U., et al. (2019). 'Limits of life and the habitability of mars: the ESA space experiment BIOMEX on the ISS'. Astrobiology 19, 145-157.

Deschoenmaeker, F., Bayon-Vicente, G., Sachdeva, N., Depraetere, O., Cabrera Pino, J. C., Leroy, B., et al. (2017). 'Impact of different nitrogen sources on the growth of Arthrospira sp. PCC 8005 under batch and continuous cultivationa biochemical, transcriptomic and proteomic profile. Bioresour. Technol. 237, 78-88. doi: 10.1016/j.biortech.2017.03.145

Dubertret, G., Lefort-Tran, M., and Chipaux, C. (1987). Ecological algal system in microgravity conditions. preliminary results. Eur. Symposium Life Sci. Res. Space 3, 113-115.

Fahrion, J., Fink, C., Zabel, P., Schubert, D., Mysara, M., Van Houdt, R., et al. (2020). 'Microbial monitoring in the EDEN ISS greenhouse, a mobile test facility in antarctica'. Front. Microbiol. 11:525. doi: 10.3389/fmicb.2020.00525

Farag, M. R., Alagawany, M., El-Hac, M. E. A., and Dhama, K. (2015). 'Nutritional and healthical aspects of spirulina (Arthrospira) for poultry, animals and human. Int. J. Pharmacol. 12, 36-51. doi: 10.3923/ijp.2016.36.51

Farges, B., Laroche, C., Cornet, J.-F., and Dussap, C.-G. (2009). 'Spectral Kinetic Modeling and Long-Term Behavior Assessment of Arthrospira platensis Growth in Photobioreactor Under Red (620 nm) Light Illumination. Hoboken, NJ: Wiley InterScience.

Fu, Y., Li, L., Xie, B., Dong, C., Wang, M., Jia, B., et al. (2016). 'How to establish a bioregenerative life support system for long-term crewed missions to the moon or mars'. Astrobiology 16, 925-936. doi: 10.1089/ast.2016.1477

Gitelson, I. I., Terskov, A., Kovrov, B. G., Sidko, F. Y., Lisovsky, G. M., and Okladinov, Y. N. (1976). 'Life support system with autonomous control employing plant photosynthesis'. Acta Astronautica 3, 633-650. doi: 10.1016/ 0094-5765(76)90103-x

Gitelson, J. I. (1992). 'Biological life-support systems for Mars mission'. Adv. Space Res. 12, 167-192. doi: 10.1016/0273-1177(92)90023-q

Gòdia, F., Albiol, J., Montesinos, J. L., Pérez, J., Creus, N., Cabello, F., et al. (2002). 'MELISSA: a loop of interconnected bioreactors to develop life support in Space'. J. Biotechnol. 99, 319-330. doi: 10.1016/s0168-1656(02)00222-5

Gros, J. B., Poughon, L., Lasseur, C., and Tikhomirov, A. A. (2003). 'Recycling efficiencies of $\mathrm{C}, \mathrm{H}, \mathrm{O}, \mathrm{N}, \mathrm{S}$, and P elements in a biological life support system based on microorganisms and higher plants. Adv. Space Res. 31, 195-199. doi: 10.1016/s0273-1177(02)00739-1

Häder, D. P., Richter, P. R., Strauch, S. M., and Schuster, M. (2006). 'Aquacells _-_ flagellates under long-term microgravity and potential usage for life support systems'. Microgravity Sci. Technol. 18, 210-214. doi: 10.1007/ bf02870411

Hauslage, J., Strauch, S. M., Eßmann, O., Haag, F. W. M., Richter, P., Krüger, J., et al. (2018). 'Eu:CROPIS - “euglena gracilis: combined regenerative organic-food production in space" - a space experiment testing biological life support systems under lunar and martian gravity'. Microgravity Sci. Technol. 30, 933-942. doi: 10.1007/s12217-018-9654-1

Helisch, H., Keppler, J., Detrell, G., Belz, S., Ewald, R., Fasoulas, S., et al. (2020). 'High density long-term cultivation of Chlorella vulgaris SAG 211-12 in a novel microgravity-capable membrane raceway photobioreactor for future bioregenerative life support in SPACE'. Life Sci. Space Res. (Amst) 24, 91-107. doi: 10.1016/j.lssr.2019.08.001

Henrikson, R. (2010). Spirulina World Food: How This Micro Algae Can Transform Your Health and Our Planet, Richmond:CA. Incorporated.

Hooke, L. R., Radtke, M., Garshnek, V., Teeter, R., and Rowe, J. E. (1986). USSR Space Life Sciences Digest." NASA Contractor Report 3922 (11).

Horneck, G., Klaus, D. M., and Mancinelli, R. L. (2010). 'Space microbiology'. Microbiol. Mol. Biol. Rev. 74, 121-156.

Hufenbach, B., Reiter, T., and Sourgens, E. (2014). 'ESA strategic planning for space exploration'. Space Policy 30, 174-177. doi: 10.1016/j.spacepol.2014. 07.009

Ilgrande, C., Defoirdt, T., Vlaeminck, S. E., Boon, N., and Clauwaert, P. (2019). 'Media optimization, strain compatibility, and low-shear modeled microgravity exposure of synthetic microbial communities for urine nitrification in regenerative life-support systems'. Astrobiology 19, 1353-1362. doi: 10.1089/ ast.2018.1981

Javanmardian, M., and Palsson, B. (1992). 'Design and operation of an algal photobioreactor system'. Adv. Space Res. 12, 231-235. doi: 10.1016/02731177(92)90029-w

Jimenez, C., Cossío, B. R., Labella, D., and Niell, F. X. (2003). 'The feasibility of industrial production of spirulina (Arthrospira) in southern spain'. Aquaculture 217, 179-190. doi: 10.1016/s0044-8486(02)00118-7

Junaedi, C., Hawley, K., Walsh, D., Roychoudhury, S., Abney, M. B., and Perry, J. L. (2011). "Compact and lightweight sabatier reactor for carbon dioxide reduction," in Proceeding of the 41st International Conference on Environmental Systems.

Keppler, J., Belz, S., Detrell, G., Helisch, H., Martin, J., Henn, N., et al. (2018). “The final configuration of the algae-based ISS experiment PBR@ LSR,” in Proceeding of the 48th International Conference on Environmental Systems.

Kirensky, L. V., Terskov, I. A., Gitelson, I. I., Lisovsky, G. M., Kovrov, B. G., and Okladnikov, Y. N. (1968). 'Experimental biological life support system. II. gas exchange between man and microalgae culture in a 30-day experiment. Life Sci. Space Res. 6, 37-40.

Klaus, D., Simske, S., Todd, P., and Stodieck, L. (1997). 'Investigation of space flight effects on Escherichia coli and a proposed model of underlying physical mechanisms'. Microbiology 143, 449-455. doi: 10.1099/00221287-143-2-449

Knox, J. C., and Stanley, C. M. (2015). "Optimization of the carbon dioxide removal assembly (CDRA-4EU) in support of the international space system 
and advanced exploration systems," in Proceeding of the 45th International Conference on Environmental Systems (Washington).

Lange, K. E., Lin, C. H., Duffield, B. E., and Hanford, A. J. (2003). Advanced Life Support Requirements Document', JSC-38571C, CTSD-ADV-245C. Lange2003.

Lasseur, C., Brunet, J., de Weever, H., Dixon, M., Dussap, C. G., Gódia, F., et al. (2010). 'MELiSSA: the european project of closed life support system. Gravitational. Space Biol. 23, 3-12.

Lasseur, C., and Mergeay, M. (2021). 'Current and future ways to closed life support systems: virtual MELiSSA conference'. Ecol. Eng. Environ. Protect. 1, 75-85. doi: 10.1007/978-3-030-52859-1_3

Law, J., Van Baalen, M., Foy, M., Mason, S. S., Mendez, C., Wear, M. L., et al. (2014). 'Relationship between carbon dioxide levels and reported headaches on the international space station'. J. Occup. Environ. Med. 56, 477-483. doi: 10.1097/jom.0000000000000158

Lee, C. G., and Palsson, B. Ø (1995). 'Light emitting diode-based algal photobioreactor with external gas exchange. J. Ferment. Bioeng. 79, 257-263. doi: 10.1016/0922-338x(95)90613-5

Lehto, K. M., Lehto, H. J., and Kanervo, E. A. (2006). 'Suitability of different photosynthetic organisms for an extraterrestrial biological life support system'. Res. Microbiol. 157, 69-76. doi: 10.1016/j.resmic.2005.07.011

Leys, N. M. E. J., Hendrickx, L., De Boever, P., Baatout, S., and Mergeay, M. (2004). 'Space flight effects on bacterial physiology'. J. Biol. Regul. Homeost. Agents 18, 193-199.

Li, M., Hu, D., Liu, H., Hu, E., Xie, B., and Tong, L. (2013). 'Chlorella vulgaris culture as a regulator of $\mathrm{CO} 2$ in a bioregenerative life support system'. $A d v$. Space Res. 52, 773-779. doi: 10.1016/j.asr.2013.04.014

MacElroy, R. D., and Bredt, J. (1984). 'Current concepts and future directions of CELSS'. Adv. Space Res. 4, 221-229. doi: 10.1016/0273-1177(84)90566-0

Mansell, J., Matthew, M. A., and Miller, L. (2011). "Influence of oxygenated compounds on reaction products in a microwave plasma methane pyrolysis assembly for post-processing of sabatier methane," in Proceeding of the 41st International Conference on Environmental Systems.

Mastroleo, F., Van Houdt, R., Atkinson, S., Mergeay, M., Hendrickx, L., Wattiez, R., et al. (2013). 'Modelled microgravity cultivation modulates $\mathrm{N}$-acylhomoserine lactone production in Rhodospirillum rubrum S1H independently of cell density'. Microbiology 159, 2456-2466. doi: 10.1099/mic.0.066415-0

Melis, A., Neidhardt, J., and Benemann, J. R. (1998). 'Dunaliella salina (Chlorophyta) with small chlorophyll antenna sizes exhibit higher photosynthetic productivities and photon use efficiencies than normally pigmented cells'. J. Appl. Phycol. 10, 515-525.

Montague, M., McArthur, G. H. IV, Cockell, C. S., Held, J., Marshall, W., Sherman, L. A., et al. (2012). 'The role of synthetic biology for in situ resource utilization (ISRU). Astrobiology 12, 1135-1142.

Morais, M. G., Radmann, E. M., Andrade, M. R., Teixeira, G. G., Brusch, L. R. F., and Costa, J. A. V. (2009). 'Pilot scale semicontinuous production of Spirulina biomass in southern Brazil'. Aquaculture 294, 60-64. doi: 10.1016/j. aquaculture.2009.05.009

Morist, A., Montesinos, J. L., Cusidó, J. A., and Gòdia, F. (2001). 'Recovery and treatment of Spirulina platensis cells cultured in a continuous photobioreactor to be used as food'. Proc. Biochem. 37, 535-547. doi: 10.1016/s0032-9592(01) 00230-8

Muscatello, A., and Santiago-Maldonado, E. (2012). Mars in situ resource utilization technology evaluation. in Proceeding of the 50th AIAA Aerospace Sciences Meeting including the New Horizons Forum and Aerospace ExpositionAt: Nashville, Tennessee 360.

Muys, M., Coppens, J., Boon, N., and Vlaeminck, S. E. (2018). 'Photosynthetic oxygenation for urine nitrification'. Water Sci. Technol. 78, 183-194. doi: 10.2166/wst.2018.200

Nasir, A., Strauch, S. M., Becker, I., Sperling, A., Schuster, M., Richter, P. R., et al. (2014). 'The influence of microgravity on Euglena gracilis as studied on Shenzhou 8'. Plant Biol. (Stuttg) 16, 113-119. doi: 10.1111/plb.12067

Niederwieser, T., Kociolek, P., and Klaus, D. (2018). 'A review of algal research in space'. Acta Astronautica 146, 359-367. doi: 10.1016/j.actaastro.2018. 03.026

Nowicka-Krawczyk, P., Muhlsteinova, R., and Hauer, T. (2019). 'Detailed characterization of the Arthrospira type species separating commercially grown taxa into the new genus Limnospira (Cyanobacteria)'. Sci. Rep. 9:694.
Onofri, S., de la Torre, R., de Vera, J. P., Ott, S., Zucconi, L., Selbmann, L., et al. (2012). 'Survival of rock-colonizing organisms after 1.5 years in outer space. Astrobiology 12, 508-516. doi: 10.1089/ast.2011.0736

Planel, H., Soleilhavoup, J. P., Tixador, R., Richoilley, G., Conter, A., Croute, F., et al. (1987). 'Influence on cell proliferation of background radiation or exposure to very low, chronic gamma radiation'. Health Phys. 52, 571-578. doi: 10.1097/00004032-198705000-00007

Popova, A. F., Sytnik, K. M., Kordyum, E. L., Meleshko, G. I., Sychev, V. N., and Levinskykh, M. A. (1989). Ultrastructural and growth indices of chlorella culture in multicomponent aquatic systems under space flight conditions'. Adv. Space Res. 9, 79-82. doi: 10.1016/0273-1177(89)90059-8

Poughon, L., Laroche, C., Creuly, C., Dussap, C. G., Paille, C., Lasseur, C., et al. (2020). 'Limnospira indica PCC8005 growth in photobioreactor: model and simulation of the ISS and ground experiments'. Life Sci. Space Res. (Amst) 25, 53-65. doi: 10.1016/j.lssr.2020.03.002

Poulet, L., Dussap, C. G., and Fontaine, J. P. (2020). 'Development of a mechanistic model of leaf surface gas exchange coupling mass and energy balances for lifesupport systems applications'. Acta Astronautica 175, 517-530. doi: 10.1016/j. actaastro.2020.03.048

Preu, P., and Braun, M. (2014). 'German SIMBOX on Chinese mission Shenzhou8: Europe's first bilateral cooperation utilizing China’s Shenzhou programme’. Acta Astronautica 94, 584-591. doi: 10.1016/j.actaastro.2013.08.022

Sachdeva, N., Giambarresi, G., Poughon, L., Cabrera, J. C., Leroy, B., Lasseur, C., et al. (2018a). 'Assessment of transient effects of alternative nitrogen sources in continuous cultures of Arthrospira sp. using proteomic, modeling and biochemical tools'. Bioresour. Technol. 267, 492-501. doi: 10.1016/j.biortech. 2018.07.062

Sachdeva, N., Mascolo, C., Wattiez, R., and Leroy, B. (2018b). 'Embedding photosynthetic biorefineries with circular economies: exploring the waste recycling potential of Arthrospira sp. to produce high quality by-products'. Bioresour. Technol. 268, 237-246. doi: 10.1016/j.biortech.2018.07.101

Safi, C., Zebib, B., Merah, O., Pontalier, P. Y., and Vaca-Garcia, C. (2014). 'Morphology, composition, production, processing and applications of Chlorella vulgaris: a review'. Renew. Sustain. Energy Rev. 35, 265-278. doi: 10.1016/j.rser.2014.04.007

Saleem, M., Hu, J., and Jousset, A. (2019). 'More than the sum of its parts: microbiome biodiversity as a driver of plant growth and soil health'. Ann. Rev. Ecol. Evol. Syst. 50, 145-168. doi: 10.1146/annurev-ecolsys-110617-062605

Salisbury, F. B., Gitelson, J. I., and Lisovsky, G. M. (1997). 'Bios-3: siberian experiments in bioregenerative life support'. BioScience 47, 575-585. doi: 10. $2307 / 1313164$

Sancho, L. G., de la Torre, R., Horneck, G., Ascaso, C., de Los Rios, A., Pintado, A., et al. (2007). 'Lichens survive in space: results from the 2005 LICHENS experiment'. Astrobiology 7, 443-454. doi: 10.1089/ast.2006.0046

Sarbatly, R. H., and Suali, E. (2013). 'Membrane Photobioreactor as A Device to Increase CO 2 Mitigation by Microalgae. Advances in Biofuels. Berlin: Springer.

Sax, K. (1963). 'The stimulation of plant growth by ionizing radiation'. Radiat. Bot. 3, 179-186. doi: 10.1016/s0033-7560(63)80014-9

Semenenko, V., and Vladimirova, M. (1961). 'Effect of cosmic flight conditions in the Sputnikship on the viability of Chlorella'. Physiol. Plants 8, 743-749.

Strauch, S. M., Schuster, M., Lebert, M., Richter, P., Schmittnägel, M., and Häder, D. P. (2008). "A closed ecological system in a space experiment," in Proceedings of the Symposium Life in Space for Life on Earth, 22-27.

Swickrath, M., and Anderson, M. (2012). "The development of models for carbon dioxide reduction technologies for spacecraft air revitalization," in Proceeding of the 42nd International Conference on Environmental Systems.

Takada, K., Van Keuren, S., Velasquez, L., Baker, P., and McDougle, S. (2019). "Advanced oxygen generation assembly for exploration missions," in Proceeding of the 49th International Conference on Environmental Systems.

Tobias, B., Garr, J., and Erne, M. (2011). "International space station water balance operations," in Proceeding of the 41st International Conference on Environmental Systems.

Tong, L., Hu, D., Liu, H., Li, M., Fu, Y., Jia, B., et al. (2011). 'Gas exchange between humans and multibiological life support system'. Ecol. Eng. 37, 2025-2034. doi: 10.1016/j.ecoleng.2011.08.013

Tong, L., Li, M., Hu, E., Fu, Y., Xie, B., and Liu, H. (2012). 'The fluxes of carbon, nitrogen and water in the multibiological life support system'. Ecol. Eng. 43, 91-94. doi: 10.1016/j.ecoleng.2012.01.023 
Upton, A. C. (2001). 'Radiation hormesis: data and interpretations'. Crit. Rev. Toxicol. 31, 681-695. doi: 10.1080/20014091111956

Vernerey, A., Albiol, J., Lasseur, C., and Gòdia, F. (2001). 'Scale-up and design of a pilot-plant photobioreactor for the continuous culture of spirulina platensis'. Biotechnol. Prog. 17, 431-438. doi: 10.1021/bp010010j

Verseux, C., Baqué, M., Lehto, K., de Vera, J. P. P., Rothschild, L. J., and Billi, D. (2015). 'Sustainable life support on marsthe potential roles of cyanobacteria'. Int. J. Astrobiol. 15, 65-92. doi: 10.1017/s147355041500021x

Wagner, I., Braun, M., Slenzka, K., and Posten, C. (2015). 'Photobioreactors in life support systems. Adv. Biochem. Eng. Biotechnol. 153, 143-184. doi: 10.1007/ 10_2015_327

Wang, G. H., Li, G. B., Li, D. H., Liu, Y. D., Song, L. R., Tong, G. H., et al. (2004). 'Real-time studies on microalgae under microgravity'. Acta Astronaut 55, 131-137. doi: 10.1016/j.actaastro.2004.02.005

Wang, G., Chen, H., Li, G., Chen, L., Li, D., Hu, C., et al. (2006). 'Population growth and physiological characteristics of microalgae in a miniaturized bioreactor during space flight'. Acta Astronautica 58, 264-269. doi: 10.1016/j.actaastro. 2005.11.001

Wang, G., Liu, Y., Li, G., Hu, C., Zhang, D., and Li, X. (2008). 'A simple closed aquatic ecosystem (CAES) for space'. Adv. Space Res. 41, 684-690. doi: 10.1016/ j.asr.2007.09.020

Ward, C. H., Wilks, S. S., and Craft, H. L. (1970). 'Effects of prolonged near weightlessness on growth and gas exchange of photosynthetic plants'. Dev. Ind. Microbiol. 11, 276-295.

Watson, A., Ghosh, S., Williams, M. J., Cuddy, W. S., Simmonds, J., Rey, M. D., et al. (2018). 'Speed breeding is a powerful tool to accelerate crop research and breeding. Nat. Plants 4, 23-29. doi: 10.1016/b978-0-12-821316-2.00002-9

Wheeler, R. M., Mackowiak, C. L., Stutte, G. W., Sager, J. C., Yorio, N. C., Ruffe, L. M., et al. (1996). 'NASA's biomass production chamber: a testbed for bioregenerative life support studies'. Adv. Space Res. 18, 215-224. doi: 10.1016/0273-1177(95)00880-n

Wheeler, R. M., Sager, J. C., Prince, R. P., Knott, W. M., Mackowiak, C. L., Stutte, G. W., et al. (2003). Crop Production for Advanced Life Support Systems-Observations From the Kennedy Space Center Breadboard Project, Merritt Island, FL. NASA Biological Sciences Office.

Winton, D., Isobe, J., Henson, P., MacKnight, A., Yates, S., and Schuck, D. (2016). "Carbon dioxide removal technologies for space vehicles-past, present, and future," in Proceeding of the 46th International Conference on Environmental Systems.

Wu, Q., Liu, L., Miron, A., Klímová, B., Wan, D., and Kuča, K. (2016). 'The antioxidant, immunomodulatory, and anti-inflammatory activities of Spirulina: an overview'. Arch. Toxicol. 90, 1817-1840. doi: 10.1007/s00204-016-1744-5

Zhang, J. Y., Lin, G. M., Xing, W. Y., and Zhang, C. C. (2018). 'Diversity of growth patterns probed in live cyanobacterial cells using a fluorescent analog of a peptidoglycan precursor'. Front. Microbiol. 9:791. doi: 10.3389/fmicb.2018. 00791

Conflict of Interest: The authors declare that the research was conducted in the absence of any commercial or financial relationships that could be construed as a potential conflict of interest.

Copyright $(2021$ Fahrion, Mastroleo, Dussap and Leys. This is an open-access article distributed under the terms of the Creative Commons Attribution License (CC BY). The use, distribution or reproduction in other forums is permitted, provided the original author(s) and the copyright owner(s) are credited and that the original publication in this journal is cited, in accordance with accepted academic practice. No use, distribution or reproduction is permitted which does not comply with these terms. 